\title{
Key technologies of ecological restoration and analysis of slope stability of spontaneous combustion of slag dumps in gullies
}

Guozhen Zhao ( $\sim$ zgzcumts@163.com )

Taiyuan University of Technology https://orcid.org/0000-0002-1498-2987

\section{Yiqing LYU}

Taiyuan University of Technology

\section{Shuai Wang}

Taiyuan University of Technology

Chao Liu

Taiyuan University of Technology

\section{Research}

Keywords: Spontaneous combustion, Slag dump, Ecological restoration, Slope stability, Numerical simulation

Posted Date: January 21st, 2021

DOl: https://doi.org/10.21203/rs.3.rs-147779/v1

License: (9) This work is licensed under a Creative Commons Attribution 4.0 International License. Read Full License 


\section{Abstract}

There are potential safety hazards such as spontaneous combustion, high temperature explosion, rainfall-induced landslide, and others within slag dumps in gullies, which seriously endanger the lives and property of surrounding residents. In this paper, the slag dump on the north side of Yumen River in Ximing Mine was taken as the project background. Aimed at the existing problems of environmental pollution and slope stability of the spontaneous combustion of slag dumps in gullies, the key technology of fire extinguishing by shallow jet deep hole grouting and the technology of foreign soil spray seeding with multiple soil fixation measures were put forward. The safety factor of gangue hill slopes under natural conditions, earthquakes and rainstorms was calculated by Lizheng Slope Stability Analysis Software, and the displacement field and the stress field of dangerous sections were analyzed by MIDAS GTS NX, a finite element simulation software. The calculation and analysis results show that the slope of the slag dump is in a stable state under natural conditions. Under the working conditions during earthquakes and rainstorms, the safety factor of the slope of the slag dump is decreased obviously, but the slope is still in a basically stable state. After 2 years' follow-up monitoring, the ecological restoration effect of the slag dump is good and the slope is stable.

\section{Introduction}

A large number of solid wastes will be produced in the mining process of mineral resources, which end up being piled up on the ground to form a slag dump (Hu et al. 2020; Zhou et al. 2020). There are some problems in the slopes of slag dumps, such as poor integrity, easy water accumulation and poor stability, especially the stability of high slopes, which is more severe and complicated (Zhang et al. 2019; Liang et al. 2020) . In China, there are hundreds of rock and soil slope related accidents caused by rainfalls every year. According to incomplete statistics, there are more than 4,000 landslides every year in China, among which nearly 2,000 accidents are caused by artificial slopes, and the economic losses caused by geological disasters are nearly 2 billion yuan per year (Luo et al. 2019; Yang et al. 2018). It can be seen that it is vital to study the treatment of slag dumps or waste dumps. At present, the research on the treatment of mine slag dumps at home and abroad mainly focuses on two aspects: one is the stability of slag dumps, the other is the key technology of ecological restoration of slag dumps (Zhao et al. 2018).

In the aspect of slag dump stability, since 1970s, international research has been carried out on the mine spoil technology, slag dump slope stability and its prevention measures, and countries such as the Soviet Union, Western Europe, America and Australia have made certain progress (Zhao et al. 2014; Luo Qiang. 2010). In China, the study on slag dumps started late, and the earliest study on slope stability and planning of slag dumps was the high-level slag dumps of the Panzhihua Iron Mine and the Nanfen Openpit Iron Mine during the Seventh Five-Year Plan period. In theoretical research, the Swedish method of slices was first used in the early 20th century, and then Fellenius, Bishop, Morgenstern, Price, Jambu and many other scholars improved such method. There are differences and connections among all the methods; all of them, however, can be collectively called limit equilibrium theory. In recent 20 years, the above limit equilibrium method has mainly developed from two dimensions to three dimensions by 
taking into account the influence of groundwater and earthquakes $₫$ Gong et al. 2017; Zhang et al. 2016区. The influence of different slope conditions, natural conditions and working conditions on slope stability was studied in depth (Xu et al. 2015; Wan et al. 2015; Yao et al. 2019; Jiang et al. 2020; Wang et al. 2019; Chun et al. 2013). In the key technology of ecological restoration of slag dumps, the waste in mine slag dumps is mainly coal gangue, especially the one with spontaneous combustion tendency, which will spontaneously combust after accumulation (Wu et al. 2018; Onifade M. and Genc B.. 2019). Therefore, the key technology of ecological restoration of mine slag dumps is fire extinguishing technology of slag dumps, followed by vegetation restoration technology (Liu et al. 2014; Liu et al. 2018). The control technology of spontaneous combustion of coal gangue has evolved from the early method of removing fire sources and covering irrigation to many comprehensive control measures in around 2000, such as deep grouting, surface shotcrete and compaction reclamation, each of which has its own advantages and disadvantages. Many methods are often used in combination in practical work (Qian et al. 2020). Vegetation restoration technology pays more attention to the matrix improvement of weathered coal gangue and the selection of vegetation species. The matrix improvement of weathered coal gangue includes chemical improvement of weathered coal gangue, mineral fertilizer improvement, foreign soil amelioration and biological improvement. The selected planting species should be drought resistant, high-temperature resistant, barren-resistant, salt-resistant, pollution-tolerant, and fast-growing, with developed roots and strong soil improvement. Besides, local plant species should be selected as much as possible (Fu et al. 2012).

Slope stability and ecological restoration of slag dumps are very complex systematic projects. In this paper, the key technologies of ecological restoration and the analysis of the slope stability of spontaneous combustion of slag dumps in gullies are focused.

\section{Overview Of Projects Of Slag Dumps In Gullies}

\subsection{Overview of Slag Dump Projects on North Side of Yumen River}

The slag dump on the north side of Yumen River is located in the south of Ximing Coal Mine of Shanxi Xishan Coal and Electricity Power Co., Ltd. The main deposits in the slag dump are boiler slag and coal gangue, with a total amount of about $240,000 \mathrm{~m}^{3}$. The lower part of the slag dump is a gully with a northsouth orientation, and the terrain is high in the north and low in the south, with a length of about $240 \mathrm{~m}, \mathrm{a}$ width of about $90 \mathrm{~m}$ and a depth of about $60 \mathrm{~m}$, covering an area of $33 \mathrm{mu}$. The slag dump is a rocky mountain area. Slag and stone are dumped naturally from top to bottom, and are piled up in a single-step pressing slope toe type. The slope surface is covered by loess, construction waste, and others, but the rest are exposed, with less than $5 \%$ of the vegetation coverage rate. Field investigation is shown in Fig. 1 , aerial photography of UAV in Fig. 2, and satellite images in Fig. 3.

\subsection{Environmental impact of the slag dump on the north side of Yumen}


(1) Danger of landslide. Because slag stones and waste rocks have been accumulated in the slag dump for many years without been crushed, and the slope is steep, in case of heavy precipitation or continuous rain, it is easy to collapse and landslide, which seriously threatens the highway under the slope. At the same time, the surface of the slag dump is exposed, which has certain influence on the landscape of the planned leisure activity area.

(2) Serious sand raising and dust raising Through investigation, it has been found that the uncovered area of the slag dump on the north side of Yumen River covers an area of $33,828 \mathrm{~m}^{2}$, which produces a large amount of sand and dust, causing pollution to the atmospheric environment and affecting the surrounding environment quality.

(3) Serious water and soil losses According to field investigation, it has been found that there is no drainage system on the slope of the slag dump, and there are obvious traces of rain erosion on the slope, resulting in serious water and soil losses. In the process of solid waste piling, the water leached out directly flows into the Yumen River downstream system, causing indirect pollution in Fenhe River.

\subsection{Key Issues and Technical Difficulties}

(1) The deep temperature of the slag dump is high, and spontaneous combustion is serious. There are waste rocks piled up at the top of the slag dump. The spontaneous combustion in the east side is serious. Moreover, there are many high temperature points on the slope. During the field investigation in the west side, a large number of waste rock piles, about 50,000 $\mathrm{m}^{2}$, were found, and no relevant treatment was carried out. Through aerological sounding using UAV's thermal imager detection technology (Ren et al. 2019), it was found that there was high temperature and spontaneous combustion at a depth of $4 \mathrm{~m}$ below the top, with a temperature of $378.8^{\circ} \mathrm{C}$ and an area of about $4500 \mathrm{~m}^{2}$. The slope temperature was $135-274^{\circ} \mathrm{C}$, accompanied by abnormal high temperature, covering an area of about $7,900 \mathrm{~m}^{2}$. The slag dump is basically oriented towards a sunny surface, and the surface temperature is relatively high in summer. See Fig. 4 for spontaneous combustion at the slag dump, and Fig. 5 for the thermal image of the slag dump.

(2) The slag dump has a large dip angle with a hidden danger of landslide. After years of accumulation of ash and waste rocks, the slag dump has a height difference of $60 \mathrm{~m}$ and a slope of about $57^{\circ}$, and therfore, there are geological hazards such as landslides. The bottom of the slag dump is close to Yumen River and highways, and the top of the slope is close to the parking lot, which has serious potential safety hazards, as shown in Fig. 2.

\section{Studies On Key Technologies Of Ecological Restoration Of The Slag Dump}

\subsection{Key Technologies of Fire Extinguishing by Shallow Jet Deep Hole Grouting}


Based on the research on the mechanism of spontaneous combustion in slag dumps at home and abroad, the spontaneous combustion of combustible materials such as gangue is regarded as the sign of spontaneous combustion, and the acceleration of self-heating of sulfide materials along with the spontaneous combustion of carbon materials are regarded as the critical points of spontaneous combustion. The spontaneous combustion of gangue can be divided into four periods: spontaneous combustion incubation period, spontaneous combustion occurrence period, spontaneous combustion development period and spontaneous combustion decline period (Wei et al. 2016), as shown in Table 1. The promoting effects of the three elements of combustion are different in various periods, and the influencing factors of mountain structure and landform characteristics are also different.

Table 1 Division standard of spontaneous combustion control of coal gangue hills

\begin{tabular}{|c|c|c|c|c|c|}
\hline $\begin{array}{l}\text { Spontaneous } \\
\text { combustion } \\
\text { stage }\end{array}$ & $\begin{array}{l}\text { Physical } \\
\text { phenomenon }\end{array}$ & Internal change & $\begin{array}{l}\text { Critical } \\
\text { temperature }\end{array}$ & $\begin{array}{l}\text { Overall } \\
\text { conditions } \\
\text { of gaunge } \\
\text { hills }\end{array}$ & $\begin{array}{l}\text { Division of } \\
\text { spontaneous } \\
\text { combustion } \\
\text { control }\end{array}$ \\
\hline $\begin{array}{l}\text { Spontaneous } \\
\text { combustion } \\
\text { incubation } \\
\text { period }\end{array}$ & $\begin{array}{l}\text { No sign, and the } \\
\text { local area was } \\
\text { getting damp }\end{array}$ & $\begin{array}{l}\text { Internal slow } \\
\text { temperature } \\
\text { increase }\end{array}$ & $\begin{array}{l}\text { Inner layer } \\
\text { of } \\
\text { occurrence } \\
\text { area }<90^{\circ} \mathrm{C}\end{array}$ & $\begin{array}{l}\text { No obvious } \\
\text { change }\end{array}$ & Safe area \\
\hline $\begin{array}{l}\text { Spontaneous } \\
\text { combustion } \\
\text { occurrence } \\
\text { period }\end{array}$ & $\begin{array}{l}\text { There was } \\
\text { smoke, peculiar } \\
\text { smell, and local } \\
\text { sulfur spots or } \\
\text { whitening } \\
\text { phenomena }\end{array}$ & $\begin{array}{l}\text { Sulfur } \\
\text { spontaneous } \\
\text { combustion } \\
\text { with rapid } \\
\text { internal } \\
\text { temperature } \\
\text { increase }\end{array}$ & $\begin{array}{l}90^{\circ} \mathrm{C}< \\
\text { inner layer } \\
\text { of } \\
\text { occurrence } \\
\text { area }< \\
280^{\circ} \mathrm{C}\end{array}$ & $\begin{array}{l}\text { Smoke } \\
\text { curled up } \\
\text { and } \\
\text { vegetation } \\
\text { degraded }\end{array}$ & Danger area \\
\hline $\begin{array}{l}\text { Spontaneous } \\
\text { combustion } \\
\text { development } \\
\text { period }\end{array}$ & $\begin{array}{l}\text { There was } \\
\text { smoke, peculiar } \\
\text { smell, } \\
\text { somatosensory } \\
\text { temperature and } \\
\text { visible open } \\
\text { flame }\end{array}$ & $\begin{array}{l}\text { Spontaneous } \\
\text { combustion of } \\
\text { coal and } \\
\text { continuous } \\
\text { combustion of } \\
\text { combustibles }\end{array}$ & $\begin{array}{l}\text { Inner layer } \\
\text { of } \\
\text { occurrence } \\
\text { area > } \\
280^{\circ} \mathrm{C}\end{array}$ & $\begin{array}{l}\text { Without } \\
\text { vegetation, } \\
\text { the } \\
\text { temperature } \\
\text { increased } \\
\text { as a whole }\end{array}$ & $\begin{array}{l}\text { High risk } \\
\text { area }\end{array}$ \\
\hline $\begin{array}{l}\text { Spontaneous } \\
\text { combustion } \\
\text { decline } \\
\text { period }\end{array}$ & $\begin{array}{l}\text { Smokeless, } \\
\text { smellless, with } \\
\text { somatosensory } \\
\text { temperature and } \\
\text { visible open } \\
\text { flame }\end{array}$ & $\begin{array}{l}\text { Combustible } \\
\text { reduction }\end{array}$ & $\begin{array}{l}\text { Inner layer } \\
\text { of } \\
\text { occurrence } \\
\text { area > } \\
280^{\circ} \mathrm{C}\end{array}$ & $\begin{array}{l}\text { Without } \\
\text { vegetation, } \\
\text { the } \\
\text { temperature } \\
\text { drops as a } \\
\text { whole }\end{array}$ & $\begin{array}{l}\text { High risk } \\
\text { area }\end{array}$ \\
\hline
\end{tabular}

Combined with the detection results of thermal imager and practical experience, the slag dump on the north side of Yumen River has been in the period of spontaneous combustion occurance and development, which needed to be addressed based on rapid cooling and blocking oxygen supply channel. The main methods included digging, grouting and covering were adopted to control and extinguish fire. 
Before the remediation of the slope, the UAV thermal imager, the hand-held infrared thermal imager and the thermocouple were used to find the high temperature point and spontaneous combustion area in the slag dump, the location and the area of the fire site were determined, and the site on fire was clearly marked. Spontaneous-combustion or high-temperature gangue was directly dug out by the excavator at the site of the combustion source of the slag dump, then directly covered with colloid or mud fire extinguishing materials for fire extinguishing, and finally backfilled to the slag dump after cooling, with the dump formed into shape. In order to prevent the slag dump from re-igniting, after the slope cutting and reshaping of the slag dump, the whole dump was shut and isolated by shallow jet grouting, with the slope surface first followed by berms, and gradually closed from bottom to top, with a closed isolation thickness of $20 \mathrm{~mm}$. Shallow jet grouting relies on high-speed mud impact infiltration together with flowing and leakage to block the gap of shallow gangue. After solidification, most air flow and water leakage channels are blocked. By limiting the communication and contact between water that promotes oxidation and warming, and oxygen that helps combustion in the gangue, three elements of controlling combustion are combined, and fire prevention and extinguishing are achieved. After the surface slurry is sealed, it is necessary to continue to monitor the temperature field of the gangue hill, pay attention to the temperature changes in the high temperature area and the deep combustion area, delimit the combustion area for the continuous high temperature points combined with the survey data, and then take deep hole grouting to eliminate the deep fire source. See Fig. 6 for the fire extinguishing site of the slag dump.

\subsection{Foreign Soil Spray Seeding Technology with Multiple Soil Fixation Measures}

Seeds, along with liquids, fibers, silty materials and particles required for plant growth were uniformly mixed, and were sprinkled on the surface of the construction slope to be restored by a high-power ejector to form a uniform blanket. Covers were interconnected and attached to the ground by the fibers with interweaving properties and solutions with caking properties, creating the growth conditions of primary plants. The outer layer formed a jelly film to keep the interior moist, which was able to not only prevent soil erosion, but also conserve water, and fix and protect seeds. As a good growth medium for plant seeds, it could help rapidly recover vegetation.

\section{(1) Earthing and slope protection projects}

Excavators were used to borrow earth at the designed borrow points. Earth was dumped on the road and the slope. From top to bottom, Earth was dumped on the slope first and then on berms. The thickness of slope earthing was $200 \mathrm{~mm}$, and that of berm earthing was $900 \mathrm{~mm}$. The transverse and longitudinal slopes were controlled during filling. The slope protection project was fixed by $500 \times 500 \times 50 \mathrm{~mm}$ largearea integral geocell and U-shaped steel chisels to ensure slope stability. Loess was chosen as earthing, first covering the soil layer on the slope. The covered loose soil should be about $50 \mathrm{~mm}$ thicker than the design thickness. First, the slope soil was levelled with an excavator, then local unevenness was manually cleaned or large stones picked up. Then the excavator was used to pat and compact slope earthing. The earthing of berms was divided into two layers: loess was adopted for the first layer with a thickness of about $600 \mathrm{~mm}$ laid from the berm mouth and compacted, which not only ensured that the isolation layer 
was not damaged, but also made it convenient for earth-moving vehicles to enter and exit. The second layer was covered with residual loess from the inside to the berm mouth, and the last layer done by the excavator in cooperation with manpower to ensure the smoothness of the final earthing surface. The elevation control was measured while laying with leveling instrument, as shown in Fig. 7(a).

(2) Nutrition layer spray seeding

Nutrient mud, with $100 \mathrm{~mm}$ of the thickness, was sprayed on loess. The nutrient layer was sprayed by professional machinery for three times. The slope was first sprayed and berms later, and spraying was carried out from top to bottom and from left (right) to right (left). The amount of material sprayed from the nozzles was uniform and consistent, ensuring the same thickness sprayed at each place, as shown in Fig. 7(b).

(3) Spraying grass seeds on the surface

After the last layer of the nutrient layer was sprayed, the grass seeds were sprayed on the surface before drying. The grass seeds were stirred evenly in the spray seeding machine, so that the sprayed grass seeds could be evenly sown on the ground. Special spray seeding machines were used. The grass seeds, fertilizers, fiber materials, and others, which were added into the water of the mixing tank, were sprayed on the surface of the nutrient layer by a jet pump through a pipeline and a spray gun at a pressure high enough to form a soft and stable spraying seeding layer. Under suitable conditions, the grass seeds would sprout and grow quickly, as shown in Fig. 7(c).

\section{(4) Water channel installation}

Semi-flexible U-shaped canals were adopted to berm canals, and resin U-shaped canal and load-bearing cast iron rain grates to crossing canals. Before the excavation of berm canals, the compactness of berms should be ensured, and the excavation line be laid out according to the position of design drawings.

Small excavators were used. When mechanical excavation reached $50 \mathrm{~mm}$ above the base, the remaining earthwork was excavated manually to the elevation required by design. After the canal excavation was completed, the foundation was cleaned manually. M7.5 cement mortar was adopted for the foundation of the canal, and for stabilization around the canal. Plain soil backfill should be dense. The water channel installation should be carried out after the completion of the earthing layer and before the start of the nutrient layer. After the canal was installed, the top surface elevation should be $100 \mathrm{~mm}$ higher than the earthing layer. After spray seeding on the nutrient layer, the top surface elevation was consistent with that of the nutrient layer.

(5) Micro-spraying projects

The micro-irrigation technology was used to maintain the vegetation in the later period. Micro-spraying was designed to directly connect a main pipe from the top platform to the middle of Platform No.1, and each platform was connected with branch pipes from the middle main pipe. A micro-spraying belt was separated at a distance of $5 \mathrm{~m}$ on the branch pipes of each platform. The length of the micro-spraying 
belt was half the distance from the platform to the slope surface of the next platform, as shown in Fig. $7(d)$.

\section{Status Quo Of Ecological Restoration Of The Slag Dump}

After treatment, the total width of the slag dump on the north side of Yumen River was $125 \mathrm{~m}$, the height was $55 \sim 62 \mathrm{~m}$, and the overall slope changed from $57^{\circ}$ to $40^{\circ}$. Five steps were formed on the west side with an average width of $4.8 \mathrm{~m}$ and four steps on the east side with an average width of $5 \mathrm{~m}$ and a slope ratio of 1:1.9. No. 1 Berm was as high as the top of retaining walls. No. 2 Berm was 1,106 m high. No. 3 Berm was 1,121 m high. No. 4 Berm was $1,136 \mathrm{~m}$ high. No. 5 Berm was 1,145 m high. The top platform of the slag dump was 1,150.1 $\mathrm{m}$ high. The longitudinal intercepting ditch was built around the slope, and the berm drainage ditch was built on each platform, which was connected with the surrounding longitudinal intercepting ditch. Masonry retaining walls were built, with a length of $255 \mathrm{~m}$, a height of $6.0 \mathrm{~m}$, a top width of $1.5 \mathrm{~m}$, a slope of 1:0.05, and a back slope of 1:0.16. The new geogrid was fixed with anchor rods for slope protection. Grass and shrubs were sprayed all over the slag dump. Evergreen trees were planted round on berms and platforms. Some areas were afforested, and irrigation systems were added. Microirrigation technology, with drizzle-like spraying irrigation, was adopted, so that maintenance was uniform and the whole area was irrigated. While the natural ecological environment was being restored, landscape design was carried out on the top platform of the slag dump. See Fig. 8 for the status quo of ecological restoration of the slag dump.

\section{Analysis Of Slope Stability After Treatment Of The Slag Dump}

Three typical profiles A (a-a'), B (b-b') and C (c-c') were selected as the profiles for stability calculation and analysis (Fig. 9 and Fig. 10).

In combination with the collected data and the engineering geology manual, empirical values were selected as calculation parameters. The calculated values are shown in Table 2.

Table 2 Suggestions of soil body parameters for stability calculation

\begin{tabular}{|llll|}
\hline Rock stratum name & $\begin{array}{l}\text { Volumetric weight (natural) } \\
\mathrm{kN} / \mathrm{m}^{3}\end{array}$ & $\begin{array}{l}\text { Cohesion } \\
\mathrm{C} / \mathrm{kPa}\end{array}$ & $\begin{array}{l}\text { Internal friction angle } \\
\varphi{ }^{\circ}\end{array}$ \\
\hline Surface earthing & 18 & 20 & 22.4 \\
\hline coal gangue & 14 & 5 & 36.5 \\
\hline $\begin{array}{l}\text { Original slope } \\
\text { earthing }\end{array}$ & 21 & 10 & 30 \\
\hline Sandstone & 23.9 & 3500 & 46.1 \\
\hline
\end{tabular}

\subsection{Theoretical Analysis of Limit Equilibrium}


The transfer coefficient method (Ding et al. 2017) was used to calculate slope stability. Its basic principle is that the difference between the sliding force parallel to the sliding surface and the anti-sliding force on any block of slip mass is residual thrust, and residual thrust is transferred down block by block from top to bottom, as shown in Fig. 11. Assuming that the residual thrust of the last block is 0 , the limit equilibrium equation is established and the stability coefficient is obtained.

The Lizheng Slope Stability Analysis Software of Lizheng Geotechnical Software was used for calculation, and the safety factor was calculated by adopting the "arc" sliding surface. General methods were formally adopted. The Swedish slice method was adopted for calculation, and the total stress method was adopted for the calculation of soil body stress.

The following three working conditions were considered. In working condition 1, natural working conditions were only affected by dead weight. In working condition 2 , natural working conditions were affected by dead weight and earthquakes. In working condition 3, natural working conditions were affected by dead weight and rainstorms. The calculation results are shown in Table 3.

Table 3 Stability calculation results

\begin{tabular}{|lllll|}
\hline \begin{tabular}{|} 
Section \\
No.
\end{tabular} & Calculated working conditions & $\begin{array}{l}\text { Stability } \\
\text { coefficient }\end{array}$ & $\begin{array}{l}\text { Stability } \\
\text { state }\end{array}$ & $\begin{array}{l}\text { Regulated standard } \\
\text { safety coefficient }\end{array}$ \\
\hline a-a' & $\begin{array}{l}\text { Working condition 1: dead } \\
\text { weight }\end{array}$ & 1.177 & $\begin{array}{l}\text { Basically } \\
\text { stable }\end{array}$ & 1.3 \\
\hline a-a' & $\begin{array}{l}\text { Working condition 2: dead } \\
\text { weight+earthquakes }\end{array}$ & 1.067 & $\begin{array}{l}\text { Basically } \\
\text { stable }\end{array}$ & 1.1 \\
\hline a-a' & $\begin{array}{l}\text { Working conditions 3: dead } \\
\text { weight+rainstorms }\end{array}$ & 1.051 & $\begin{array}{l}\text { Basically } \\
\text { stable }\end{array}$ & 1.1 \\
\hline b-b' & $\begin{array}{l}\text { Working condition 1: dead } \\
\text { weight }\end{array}$ & 1.306 & Stable & 1.3 \\
\hline b-b' & $\begin{array}{l}\text { Working condition 2: dead } \\
\text { weight+earthquakes }\end{array}$ & 1.198 & Stable & 1.1 \\
\hline b-b' & $\begin{array}{l}\text { Working conditions 3: dead } \\
\text { weight+rainstorms }\end{array}$ & 1.115 & Stable & 1.1 \\
\hline c-c' & $\begin{array}{l}\text { Working condition 1: dead } \\
\text { weight }\end{array}$ & 1.305 & Stable & 1.3 \\
\hline c-c' & $\begin{array}{l}\text { Working condition 2: dead } \\
\text { weight+earthquakes }\end{array}$ & 1.183 & Stable & 1.1 \\
\hline c-c' & $\begin{array}{l}\text { Working conditions 3: dead } \\
\text { weight+rainstorms }\end{array}$ & 1.138 & Stable & 1.1 \\
\hline
\end{tabular}

Through the calculation Lizheng Software, Section a-a' was basically stable under three working conditions, and Section b-b' and Section c-c' were stable under three working conditions. 


\subsection{Numerical Simulated Calculation of Slope Stability in the Slag Dump}

The initial stress field of the mechanical model was calculated, and then the strength of rock and soil was continuously reduced by the strength reduction method, so that the non-convergence state was reached. Finally, according to the distribution law of the stress field of the studied model, the corresponding failure points and the failure surfaces were found, and the critical reduction coefficient was the safety factor. The model should comply with Mohr-Coulomb criterion, that is, cohesion and the internal friction angle of geotechnical materials are the factors that determine the shear failure. When the shear stress of the research object exceeds the cohesion of geotechnical materials and the shear stress controlled by internal frictions, shear failure will occur to geotechnical materials (Yang et al. 2019). In numerical simulations, MIDAS GTS NX Finite Element Simulation Software was used to calculate and analyze the displacement field and the stress field of gangue hill slopes. The calculation model is shown in Fig. 12.

The three main sections A (a-a'), B (b-b') and C (c-c') in Fig. 12 were the basic objects of numerical simulation analysis. A two-dimensional numerical simulation model was established to simulate stress distribution and displacement deformation under natural working conditions only affected by dead weight, and results were then compared with the theoretical calculation results.

The mechanical boundary condition of the model is a constraint with left and right ( $X$ direction) and bottom ( $Y$ direction). The elastic-plastic model with the Mohr-Coulomb failure criterion was adopted for model calculation. The soil body parameters were the same as those calculated by Lizheng.

\subsubsection{Numerical simulation results of the Section a-a model}

Under natural working conditions, the numerical simulation stability coefficient of Section a-a is 1.232 , which is slightly larger than the safety coefficient calculated by Lizheng Software. The area with large deformation in the numerical simulation results is basically consistent with the position of the most dangerous sliding surface calculated by Lizheng. The range with large deformation in the numerical simulation is slightly larger than that of the most dangerous sliding surface. The displacement result of the numerical simulation is shown in Fig. 13.

The results of Fig. 13 demonstrate that the maximum total displacement of the model is located at the foot of the lowest slope, and the total displacement is $0.076 \mathrm{~m}$. The maximum horizontal displacement is $0.066 \mathrm{~m}$ in the middle and lower part of the lowest grade slope, and the maximum vertical displacement is $0.069 \mathrm{~m}$ at the junction of coal gangue and miscellaneous fill soil at the top of the slope. There is a slight upward uplift at the foot of the slope with a displacement of $0.04 \mathrm{~m}$.

Fig. 14 shows the stress distribution of numerical simulation of Section a-a'.

The results of the numerical simulation of stress nephogram of Section a-a' in Fig. 14 show that the maximum horizontal and vertical stress values of model slopes are located at the foot of retaining walls, but both stress values are very small, which have little influence on the stability of retaining walls. 


\subsubsection{Numerical simulation results of the Section b-b model}

Under natural working conditions, the stability coefficient of numerical simulation of Section b-b is 1.336 , which is slightly larger than the safety coefficient calculated by Lizheng Software. The area with large deformation in the numerical simulation results is basically consistent with the position of the most dangerous sliding surface calculated by Lizheng. The range with large deformation in the numerical simulation is slightly larger than the range of the most dangerous sliding surface. The displacement result of the numerical simulation is shown in Fig. 15.

The results of Fig. 15 show that the maximum total displacement and the maximum horizontal displacement of the model are located between the No.2 and No.3 berms, both of which are about 0.093 $\mathrm{m}$. The maximum vertical downward displacement is $0.069 \mathrm{~m}$ at the top platform. There is a slight upward uplift at the foot of the slope, with the displacement of about $0.028 \mathrm{~m}$.

Fig. 16 shows the stress distribution in the numerical simulation of Section b-b'.

The results of numerical simulation of stress nephogram of Section b-b' in Fig. 16 show that the maximum stress values of model slopes in horizontal and vertical directions are located at the top platform of retaining wall, but both stress values are very small, which have little influence on slope stability.

\subsubsection{Numerical simulation results of Section $c-c^{\prime}$}

Under natural working conditions, the numerical simulation stability coefficient of Section c-c' is 1.375 , which is slightly larger than the safety coefficient calculated by Lizheng Software. In the numerical simulation results, the position of the most dangerous sliding surface is basically consistent with that calculated by Lizheng, and the range of the numerical simulation deformation area is slightly larger than that of the most dangerous sliding surface. The numerical simulation displacement results are shown in Fig. 17.

The results of Section c-c' in Fig. 17 show that the maximum total displacement of the model and the maximum horizontal displacement are located between the No.3 berm and No.4 berm. Both values are about $0.09 \mathrm{~m}$. The maximum vertical downward displacement is $0.0745 \mathrm{~m}$ at the top of the slope. There will be a slight upward uplift at the No.3 berm platform, with about $0.02 \mathrm{~m}$ of the displacement.

The results of the numerical simulation of stress nephogram of Section c-c' in Fig. 18 show that the maximum horizontal stress value of the model is $15.74 \mathrm{kN}$ at the top platform of the slope. The maximum vertical stress value is $4.66 \mathrm{kN}$ between the No.4 platform and the top of the slope. Both stresses are small and have little influence on slope stability.

\section{Conclusions}


(1) The ecological restoration of the slope of the slag demp is a complex systematic project. The key technology of fire extinguishing by shallow jet deep hole grouting can effectively block most air flow and water leakage channels, and prevent and extinguish fire by limiting the combined three elements of combustion. The technology of foreign soil spray seeding with multiple soil fixation measures can prevent soil erosion, conserve water, fix and protect seeds, and enhance the survival rate of vegetation.

(2) Through rational calculation and analysis, it can be concluded that the slope of the slag dump under ecological restoration on the north side of Yumen River is in a stable state as a whole, and the positions of the most dangerous sliding surfaces of the three sections are different. However, the affected areas are all limited to the surface earthing layer and the coal gangue layer, and the slope of coal gangue hills may be slightly deformed locally. Under the working conditions during earthquakes and rainstorms, the safety factor of the slope of the slag dump under ecological restoration on the north side of Yumen River is decreased obviously, but it remained basically stable.

(3) MIDAS GTS NX was used analyze the displacement field and the stress field of gangue hill slopes. Finally, according to the distribution law of the stress field of the studied model, the corresponding failure points and failure surfaces were found. The results show that under natural working conditions, the slope of the slag dump under ecological restoration on the north side of Yumen River is in a stable state. After 2 years' follow-up monitoring, the ecological restoration effect of the slag dump is good and the slope is stable.

\section{Declarations}

\section{Acknowledgements}

The authors gratefully acknowledge the financial support provided by the National Natural Science Foundation of China (Grant Number 51904199).

\section{Compliance with ethical standards}

\section{Conflict of interest}

All authors declare that they have no conflict of interest or financial conflicts to disclose.

\section{Open Access}

This article is distributed under the terms of the Creative Commons Attribution 4.0 International License (http://crea tivecommons.org/licenses/by/4.0/), which permits unrestricted use, distribution, and reproduction in any medium, provided you give appropriate credit to the original author(s) and the source, provide a link to the Creative Commons license, and indicate if changes were made.

\section{References}


Hu ZQ, Xiao W, Zhao YL. Re-discussion on coal mine eco-environment concurrent mining and reclamation. Journal of China Coal Society, 2020,45( 1):351-359.

Zhou N, Yao YN, Song WJ, He ZW, Meng GH, Liu Y. Present situation and prospect of coal gangue treatment technology. Journal of Mining \& Safety Engineering, 2020,37(01):136-146.

Zhang Y, Yang XY, Tighe S. Evaluation of Mechanical Properties and Microscopic Structure of Coal Gangue after Aqueous Solution Treatment. Materials (Basel, Switzerland), 2019,12(19).

Liang YC, Liang HD, Zhu SQ. Mercury emission from spontaneously ignited coal gangue hill in Wuda coalfield, Inner Mongolia, China. Fuel,2016,182.

Luo H, Deng C, Zhao GW. Statistics and preliminary analysis for typical landslide dams in China in past decade. Advances in Science and Technology of Water Resources.,2020,40(01):17-24.

Yang LY, Li HH. The construction of the restoration fund for mine environment system in China. China Mining Magazine, 2018,27(12):77-82.

Zhao HB, Wei ZQ, Luo K, et al. Stability and control measures of open-pit mine dump slope under rainfall conditions. Coal Science and Technology, 2019,47( 10):67-74.

Zhao TY. Markov Chain Monte Carlo-based stability analysis for Ping Zi shan landslide. Southwest Jiaotong University,2014.

Luo Q. Stability study for rock slope and anchoring parametric analysis. Central South University,2010.

Gong WH, Chen XL, Qiu JW, Wang J, Zhong XH. Seismic stability analysis of soil slope using theory of slip line field. Rock and Soil Mechanics, 2017,38(06):1733-1738.

Zhang JW, Zou Y, Li YL. Failure mechanism and stability analysis of big multi-layer deposit. Chinese Journal of Rock Mechanics and Engineering, 2016,35(12):2479-2489.

Xu XT, Jian WB. Dynamic response of pengkeng landslide to rainfall and its monitoring and early waring. Journal of Engineering Geology, 2015,23(02):203-210.

Wan BH, Zhao YX, Wang N, Hu YZ. Study on the impact of earthquakes and precipitation on slope stability. World Earthquake Engineering, 2015,31(04):165-169.

Yao GQ, Yan ZX, Long Z, Xiao P. Research on the influence of anchor support parameters on soil slope stability based on orthogonal design. Highway, 2019,64(01):37-45.

Jiang TJ, Jian WX, Yao Y, Tian PF, Zhang SP. Slpoe stability analysis of granite weathering zone based on improved Green-Ampt rainfall infiltration model. Safety and Environmental Engineering, 2020,27(02):5865. 
Wang F, Zou ZX, Yan JB. Research on slope prevention method based on seepage interception. Safety and Environmental Engineering, 2019,26(06):72-78.

Chun XJ, Xiao H, Ji HW. Orthogonal Analysis on Factors Influencing Slope Stability of Coal Gangue Dump. Advanced Materials Research, 2013,2331.

Wu YG, Yu XY, Hu SY, Shao H, Liao Q, Fan YR. Experimental study of the effects of stacking modes on the spontaneous combustion of coal gangue. Process Safety and Environmental Protection, 2018.

Onifade M., Genc B. Spontaneous combustion liability of coal and coal-shale: a review of prediction methods. Int J Coal Sci Technol 2019, 6(2): 151-168.

Liu LC, Jia J, Xu GR, Meng F. Effects of soil properties on vegetation restoration in coal-gangue pile. Journal of Nanjing Forestry University (Natural Sciences Edition), 2014,38(S1):99-104.

Liu BW, Tang ZH, Dong SG, Wang LX, Liu DW. Vegetation recovery and groundwater pollution control of coal gangue field in a semi-arid area for a field application. International Biodeterioration \&amp; Biodegradation, 2018,128.

He Q, Xiao Y, Yang M. Development trend of prevention and control technology and comprehensive control mode of gangue hill spontaneous combustion. Safety in Coal Mines, 2020,51(8):220-226.

Fu YR, Zhang JP, Dong Q, Li JB, Zhao GP, Shi CC. Vegetation restoration technologies in the coal gangue waste lands in sandy areas of northern Shanxi. Journal of Northwest Forestry University, 2012,27(05):178-183.

Ren $\mathrm{H}$, Zhao YY, Xiao W, Hu ZQ. A review of UAV monitoring in mining areas: current status and future perspectives. Int J Coal Sci Technol, 2019, 6(3):320-333.

Wei BL, Hu ZQ, Wang XJ, Zhao P, Zhao YL, Xiao W. Study on spontaneous combustion rule of gangue dump and its comprehensive control measures. Mining Safety \& Environmental Protection, 2016,43(01):92-95.

Ding WF, Zhang CL, Zhang NJ. Time-history transferring coefficient method of analysis on slope dynamic stability. Journal of Chongqing Jiaotong University (Natural Science), 2017,36(11):61-65.

Yang XM, Huo JJ, Li YR. Study on stability of slope affected by goaf based on MIDAS software. Coal Science and Technology, 2019,47(8):89-95. 